\title{
ДИНАМІКА АНТИОКСИДАНТНО-ПРООКСИДАНТНОГО БАЛАНСУ ТОНКОЇ КИШКИ ПІД ВПЛИВОМ ГОСТРОЇ КРОВОВТРАТИ, УСКЛАДНЕНОЇ ІШЕМІЄЮ-РЕПЕРФУЗІЄЮ КІНЦІВКИ, ТА ЙОГО КОРЕКЦІЯ КАРБАЦЕТАМОМ
}

Вступ. Поширення тероризму і локальних збройних конфрліктів призвело до підвищення частоти вогнепальних уражень з масивною зовнішньою кровотечею з кінцівок. Своєчасне накладання кровоспинного джгута на термін до 2 год вважають єдиним засобом рятування життя. Однак вплив гострої крововтрати й ішемії-реперфузії кінцівки на антиоксидантно-прооксидантний баланс тонкої кишки вивчено недостатньо. Немає даних щодо ефективності за цих умов карбацетаму, який проявляє антиоксидантну дію.

Мета дослідження - з'ясувати вплив гострої крововтрати, ускладненої ішемією-реперфузією кінцівки, на антиоксидантно-прооксидантний баланс стінки тонкої кишки та ефективність корекції виявлених порушень карбацетамом.

Методи дослідження. Експерименти виконано на 108 нелінійних щурах-самцях масою 200-220 г. Усіх тварин поділили на 5 груп: контрольну і 4 дослідних. Під тіопентал-натрієвим наркозом у 1-й дослідній групі моделювали ішемію-реперорузію кінцівки, у 2-й - гостру крововтрату, у 3-й - ці ушкодження поєднували. У 4-й дослідній групі щурам із гострою крововтратою та ішемією-реперфузією кінцівки внутрішньочеревно вводили карбацетам у дозі 5 мг/кг маси тіла тварини. Через 1 та 2 год, а також через 1, 7 і 14 діб у гомогенаті тонкої кишки визначали вміст реагентів до тіобарбітурової кислоти, каталазну активність, розраховували антиоксидантно-прооксидантний індекс (АПI).

Результати й обговорення. Моделювання лише ішемії-реперфузії кінцівки зумовлювало зростання величини АПІ в тонкій кишці з максимумом через 1 добу експерименту, що свідчило про домінування антиоксидантних механізмів у відповідь на сукупність системних порушень, які виникають в організмі в реперфузійний період. Під впливом гострої крововтрати величина АПІ в тонкій кишиі протягом 1 та 2 год експерименту компенсаторно збільшувалась порівняно з контролем, проте в подальшому різко зменшувалась $і$ була істотно нижчою від контролю до 14-ї доби. Поєднання ішемії-реперфузії кінцівки та гострої крововтрати спричиняло зменшення величини АПІ в тонкій кишці вже через 1 год експерименту. Впродовж усього терміну спостереження показник у цій дослідній групі був істотно нижчим, ніж у групах, в яких окремо моделювали ішемію-реперфузію кінцівки та гостру крововтрату. Введення карбацетаму нівелювало прооксидантний вплив досліджуваного ураження на тканини тонкої кишки протягом 7-14 діб застосування.

Висновки. Моделювання ішемії-реперфрузії кінцівки на тлі гострої крововтрати супроводжується зменшенням величини АПІ в тонкій кишці вже з 1 год експерименту, і впродовж усього терміну спостереження вона істотно нижча, ніж в інших дослідних групах. Застосування протягом 7-14 діб реперфузійного періоду карбацетаму сприяє збільшенню величини АПІ в тонкій кишці, що свідчить про антиоксидантну дію препарату за умов модельованої патології.

КЛЮчОВІ СЛОВА: тонка кишка; гостра крововтрата; ішемія-реперфузія кінцівки; антиоксидантно-проксидантний баланс; карбацетам.

ВСТУП. Характерною ознакою сучасного урбанізованого суспільства стало поширення тероризму і локальних збройних конфрліктів, що призвело до значного підвищення частоти вогнепальних уражень. За цих умов основною причиною смерті поранених та постраждалих визнано масивну зовнішню кровотечу з кінцівок [1]. Своєчасне застосування кровоспинного джгута на місці події вважають єдиним засобом рятування життя. Максимальний термін безпеч(c) В. В. Стрельбицька, А. А. Гудима, 2021. ної повної ішемії кінцівки внаслідок накладання джгута становить 2 год.

У ряді експериментальних досліджень показано, що повне знекровлення кінцівки протягом 2 год у реперсузійний період супроводжується сукупністю системних порушень, серед яких провідну роль відіграють посилення процесів пероксидного окиснення ліпідів (ПОЛ) та виснаження антиоксидантного захисту [2], що посилюється на тлі супутньої гострої крововтрати [3]. У зв'язку з наявністю спільних механізмів акти- 
вації пОЛ за умов ішемії-реперфузії і гострої крововтрати, пов'язаних з утворенням активних фрорм оксигену $[4,5]$, таке поєднання створює передумови для розвитку поліорганної диссрункції і недостатності $[6,7]$.

Інтенсивність патогенного впливу ПОЛ на клітинні мембрани пов'язана зі станом антиоксидантної системи. Однак вплив гострої крововтрати й ішемії-реперфузії кінцівки на антиоксидантно-прооксидантний баланс тонкої кишки вивчено недостатньо. Немає даних щодо ефективності за цих умов карбацетаму, який, завдяки антиоксидантній дії, послаблює прооксидантний вплив гострої крововтрати й ішемії-реперфузії кінцівки в печінці [3], нирках [8] та легенях [9].

Мета дослідження - з'ясувати вплив гострої крововтрати, ускладненої ішемією-реперфузією кінцівки, на антиоксидантно-прооксидантний баланс стінки тонкої кишки та ефективність корекції виявлених порушень карбацетамом.

МЕТОДИ ДОСЛІДЖЕННЯ. В експериментах використано 108 нелінійних щурів-самців масою 180-200 г, яких поділили на 5 груп: контрольну і 4 дослідних (по 6 щурів у кожній). Усі втручання виконано під тіопентал-натрієвим наркозом у дозі 40 мг·кг-1. У 1-й дослідній групі тваринам моделювали ішемію-реперфузію кінцівки. 3 цією метою на ліву лапку проксимально накладали смужку еластичного джгута "SWAT-T" (США) шириною 10 мм, який повністю припиняв кровотік протягом 120 хв. У 2-й дослідній групі шляхом пересікання стегнової вени моделювали гостру крововтрату (20 \% від об'єму циркулюючої крові). У 3-й дослідній групі ці ушкоджен- ня поєднували. У 4-й дослідній групі щурам із гострою крововтратою та ішемією-репердузією кінцівки з корегувальною метою внутрішньочеревно вводили карбацетам (Інститут фрізико-органічної хімії і вуглехімії ім. Л. М. Литвиненка НАН України, Київ) у дозі 5 мг/кг маси тіла тварини [10]. Тварин контрольної групи тільки вводили в наркоз, застосовуючи еквівалентну дозу тіопентал-натрію.

Через 1 та 2 год, а також через 1, 7 і 14 діб за умов тіопентал-натрієвого наркозу піддослідних тварин виводили з експерименту методом тотального кровопускання із серця. У гомогенаті тонкої кишки визначали вміст реагентів до тіобарбітурової кислоти (ТБК-активних продуктів ПОЛ) [11] і каталазну активність [12]. На основі отриманих даних розраховували антиоксидантно-прооксидантний індекс (АПІ = каталазна активність / вміст ТБК-активних продуктів ПОЛ) [10].

Під час роботи з лабораторними тваринами дотримувались міжнародних вимог про гуманне поводження з тваринами відповідно до правил Європейської конвенції про захист хребетних тварин, що використовуються для дослідних та інших наукових цілей (European Convention, Страсбург, 1986).

Оцінку вірогідності відмінностей між експериментальними групами проводили з використанням непараметричного критерію Манна Уітні.

РЕЗУЛЬТАТИ Й ОБГОВОРЕННЯ. ЯК ВИДНО 3 таблиці та рисунка 1, за умов ішемії-реперфузії кінцівки величина АПІ в тонкій кишці стосовно

Таблиця - Динаміка антиоксидантно-прооксидантного індексу (ум. од.) після гострої крововтрати, ускладненої ішемією-реперфузією кінцівки (Me (LQ; UQ)) - медіана (нижній і верхній квартилі)

\begin{tabular}{|c|c|c|c|c|c|}
\hline \multirow{2}{*}{ Дослідна група } & \multicolumn{5}{|c|}{ Термін реперфузійного періоду } \\
\hline & 1 год & 2 год & 1-ша доба & 7-ма доба & 14-та доба \\
\hline \multicolumn{6}{|c|}{ Контроль $=0,50(0,45 ; 0,55)(n=6)$} \\
\hline \multirow[t]{2}{*}{ 1-ша (ішемія-реперфузія) } & 0,60 & $0,91^{*}$ & $1,34^{\star}$ & $1,11^{*}$ & $1,13^{*}$ \\
\hline & $\begin{array}{c}0,52 ; 0,64 \\
(n=6)\end{array}$ & $\begin{array}{c}0,80 ; 1,04 \\
(n=6)\end{array}$ & $\begin{array}{c}1,32 ; 1,45 \\
(n=6)\end{array}$ & $\begin{array}{c}0,95 ; 1,28 \\
(n=6)\end{array}$ & $\begin{array}{c}1,06 ; 1,23 \\
(n=6)\end{array}$ \\
\hline \multirow[t]{2}{*}{ 2-га (гостра крововтрата) } & $0,73^{\star}$ & 0,57 & $0,16^{*}$ & $0,13^{*}$ & $0,19 *$ \\
\hline & $\begin{array}{c}0,68 ; 0,78 \\
(n=6)\end{array}$ & $\begin{array}{c}0,54 ; 0,58 \\
(n=6)\end{array}$ & $\begin{array}{c}0,15 ; 0,16 \\
(n=6)\end{array}$ & $\begin{array}{c}0,13 ; 0,14 \\
(n=6)\end{array}$ & $\begin{array}{c}0,20 ; 0,22 \\
(n=6)\end{array}$ \\
\hline 3-тя (ішемія-реперфузія+ & $0,40^{*}$ & $0,25^{*}$ & $0,11^{*}$ & $0,07^{*}$ & $0,08^{*}$ \\
\hline гостра крововтрата & $\begin{array}{c}0,35 ; 0,43 \\
(n=6)\end{array}$ & $\begin{array}{c}0,24 ; 0,28 \\
(n=6)\end{array}$ & $\begin{array}{c}0,09 ; 0,13 \\
(n=6)\end{array}$ & $\begin{array}{c}0,07 ; 0,13 \\
(n=6)\end{array}$ & $\begin{array}{c}0,07 ; 0,10 \\
(n=6)\end{array}$ \\
\hline$p_{1-2}$ & $<0,05$ & $<0,05$ & $<0,05$ & $<0,05$ & $<0,05$ \\
\hline$p_{1-3}$ & $<0,05$ & $<0,05$ & $<0,05$ & $<0,05$ & $<0,05$ \\
\hline$p_{2-3}$ & $<0,05$ & $<0,05$ & $<0,05$ & $<0,05$ & $<0,05$ \\
\hline
\end{tabular}

Примітки:

1. * - відмінності стосовно контрольної групи статистично вірогідні $(p<0,05)$.

2. $\mathrm{p}_{1-2}$ - вірогідність відмінностей між 1-ю і 2-ю дослідними групами.

3. $\mathrm{p}_{1-3}$ - вірогідність відмінностей між 1-ю і 3-ю дослідними групами.

4. $\mathrm{p}_{2-3}$ - вірогідність відмінностей між 2-ю і 3-ю дослідними групами. 


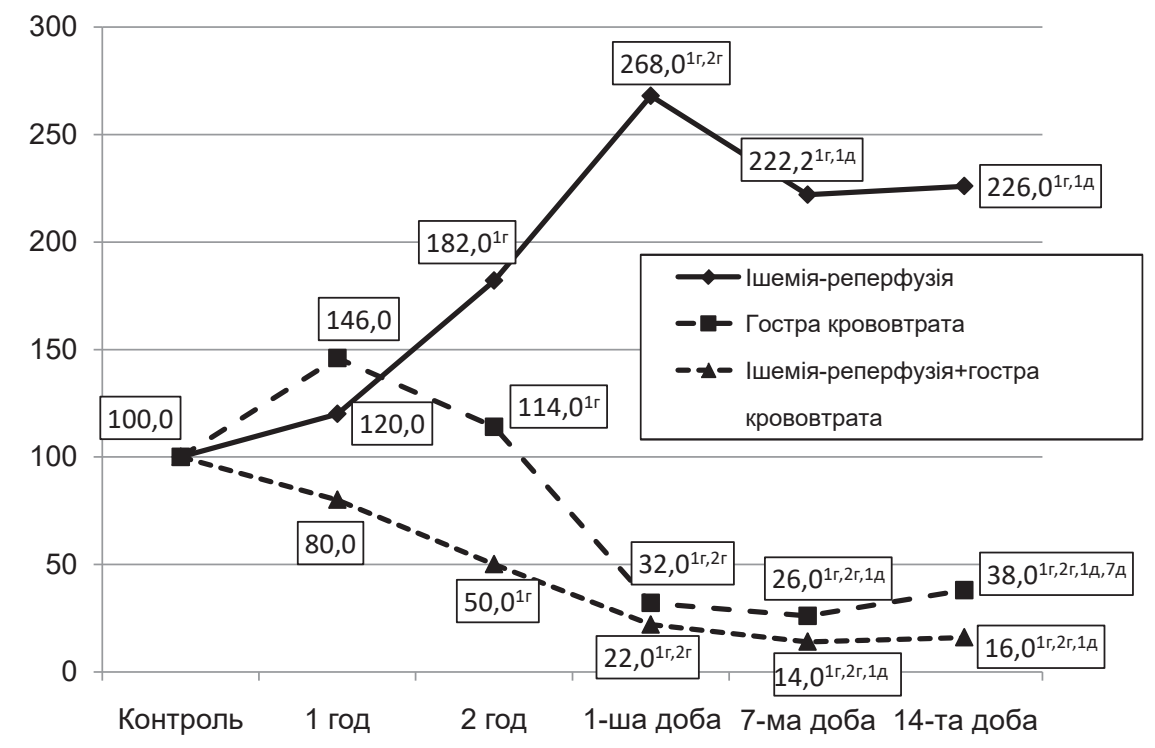

Рис. 1. Динаміка величини антиоксидантно-прооксидантного індексу в печінці (у відсотках до рівня контролю) після гострої крововтрати, ускладненої ішемією-реперфузією кінцівки.

Примітка. 1,2,г,1д,7д - відмінності стосовно, відповідно, 1 та 2 год, а також 1-ї і 7-ї діб експерименту статистично вірогідні $(p<0,05)$.

контролю зростала. Починаючи 32 год експерименту, результат виявився статистично значущим (на 82,0\%, p<0,05). У подальшому показник до 1-ї доби продовжував збільшуватись і в цей термін перевищував контроль у 2,68 раза $(p<0,05)$, а результат 1 та 2 год експерименту відповідно, у 2,23 раза і на $47,2 \%(p<0,05)$. Через 7 та 14 діб він знижувався, що було статистично значущим стосовно 1-ї доби експерименту (відповідно, на 17,2 і 15,7 \%), проте продовжував перевищувати контроль (відповідно, у 2,22 та $2,26$ раза, $p<0,05)$ і результати 1 та 2 год експерименту $(p<0,05)$.

Після моделювання гострої крововтрати (табл.) через 1 год експерименту величина АП। в тонкій кишці збільшувалася на 46,0 \% $(p<0,05)$, проте, починаючи з 2 год експерименту, вона зменшувалася і через 1, 7 та 14 діб ставала істотно нижчою від контролю (відповідно, на 68,0, $74,0$ і $62,0 \%, p<0,05)$. Як видно 3 рисунка 1 , показник досягав мінімальної величини через 7 діб, що було статистично вірогідним порівняно з усіма попередніми термінами спостереження ( $<<0,05)$, і до 14-ї доби зростав, що було статистично достовірним порівняно з 1-ю та 7-ю добами експерименту (відповідно, на 18,8 і 46,2 \%, $p<0,05)$.

Ускладнення гострої крововтрати ішемією-реперфузією кінцівки викликало зменшення величини АПІ в тонкій кишці, починаючи з 1 год експерименту (табл.). Порівняно 3 контролем показник у всі терміни дослідження виявився статистично вірогідно нижчим: через 1 год - на 20,0 \%, через 2 год- на 50,0 \%, через 1 добу - на
78,0 \%, через 7 діб - на 86,0 \%, через 14 діб - на $84,0 \%(p<0,05)$. Він досягав мінімальної величини через 7 діб, що виявилося статистично значущим порівняно з 1 та 2 год і 1-ю добою експерименту (відповідно, на 82,5, 72,0 та $36,4 \%, p<0,05)$.

Порівняння дослідних груп між собою показало, що в 1-й дослідній групі величина АПІ в тонкій кишці в усі терміни експерименту була статистично вірогідно більшою, ніж у 2-й і 3-й $\left(p_{1-2}<0,05, p_{1-3}<0,05\right)$. У свою чергу, в 3-й дослідній групі досліджуваний показник у всі терміни спостереження був істотно нижчим, ніж у 2-й дослідній групі (відповідно, на 45,2, 56,1, 31,5, 46,2 та $\left.57,9 \%, p_{2-3}<0,05\right)$.

Застосування карбацетаму в групі щурів, яким моделювали гостру крововтрату й ішемію-реперфузію кінцівки (рис. 2), супроводжувалося статистично значущим збільшенням величини АПІ в тонкій кишці порівняно з тваринами без корекції: через 7 діб - у 2,14 раза $(p<0,05)$, через 14 діб - у 2,5 раза $(p<0,05)$.

Отримані результати вказують на те, що моделювання лише ішемії-реперфузії кінцівки зумовлювало зростання величини АПІ в тонкій кишці з максимумом через 1 добу експерименту, що свідчило про домінування антиоксидантних механізмів у відповідь на сукупність системних порушень, які виникають в організмі в реперфрузійний період. На думку окремих авторів, останні зумовлені впливом активних фрорм оксигену, вільних радикалів та інших ендотоксинів, які надходять у системний кровотік з ішемізованої протягом 2 год кінцівки після її реперфузії [13]. 


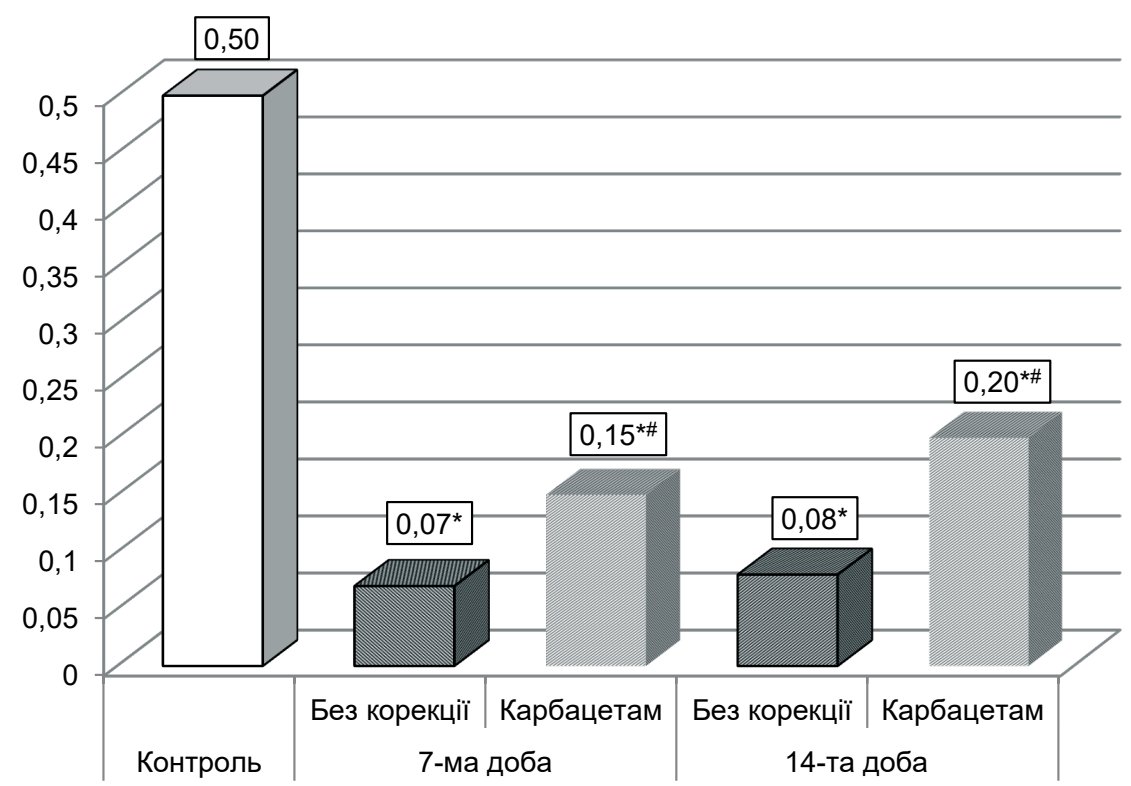

Рис. 2. Вплив карбацетаму на величину антиоксидантно-прооксидантного індексу в тонкій кишці (ум. од.) після гострої крововтрати, ускладненої ішемією-реперфузією кінцівки.

Примітка. * - відмінності стосовно контрольної групи статистично вірогідні (p<0,05); \# відмінності щодо групи без корекції статистично вірогідні $(p<0,05)$.

Подібні зміни після ішемії-реперфузії кінцівки відмічали в печінці, нирках та легенях [2], i, на думку деяких авторів, вони мають компенсаторний характер і спрямовані на знешкодження насамперед метаболітів активних фрорм оксигену. До 14-ї доби експерименту величина АПІ в тонкій кишці не досягала рівня контрольної групи, що вказувало на тривале в часі розбалансування антиоксидантних і прооксидантних механізмів.

Під впливом гострої крововтрати величина АПІ в тонкій кишці протягом 1 і 2 год експерименту компенсаторно зростала порівняно 3 контролем, проте в подальшому різко знижувалася, що свідчило про посилення прооксидантних механізмів і виснаження чинників антиоксидантного захисту. В основі активації ПОЛ за умов гострої крововтрати, очевидно, лежить розвиток гемічної гіпоксії, а також компенсаторне зменшення кровопостачання органів шлунково-кишкового тракту внаслідок перерозподілу кровотоку, спрямоване на забезпечення життєдіяльності життєво важливих органів [14].

Поєднання ішемії-реперсузії кінцівки та гострої крововтрати зумовило зменшення величини АПІ в тонкій кишці вже через 1 год експерименту. Протягом усього терміну спостереження показник у цій дослідній групі був істотно нижчим, ніж у групах, в яких окремо моделювали ішемію-реперсузію кінцівки та гостру крововтрату. Імовірно, мало місце нашарування прооксидантних механізмів як ішемії-реперсрузії кінцівки, так і гострої крововтрати, що свідчило про знач- ну чутливість тканин тонкої кишки до системних прооксидантних впливів. За даними літератури, такі порушення можуть стати пусковим моментом системної відповіді організму на запалення з розвитком поліорганної дисфуннції і недостатності [6].

3 метою корекції виявлених порушень ми застосували карбацетам, що, як зазначалося, за умов гострої крововтрати, ускладненої ішемією-реперфузією кінцівки, нівелював прооксидантний вплив цього ураження на паренхіму нирок, печінки і легень [3, 8, 9]. Результати досліджень показали, що використання препарату супроводжувалося суттєво меншим зниженням величини АПІ в тонкій кишці протягом 7-14 діб застосування. В основі його позитивної дії, очевидно, лежить антиоксидантна, імуномодулююча, детоксикуюча, мембраностабілізувальна і тканинопротекторна дія, про що свідчать результати досліджень окремих авторів [10]. Отже, карбацетам проявляє системний антиоксидантний вплив і $€$ перспективним засобом корекції прооксидантних порушень у тонкій кишці за умов гострої крововтрати, ускладненої ішемією-реперфузією кінцівки.

ВИСНОВКИ. 1. Унаслідок двогодинної ішемії та реперфузії кінцівки в тонкій кишці суттєво зростає величина АПІ з максимумом через 7 діб реперфузійного періоду, яка до 14-ї доби не досягає рівня контрольної групи і свідчить про компенсаторне посилення механізмів антиоксидантного захисту. 
2. За умов гострої крововтрати величина АП। в тонкій кишці протягом 1-2 год експерименту компенсаторно збільшується, проте в подальшому різко зменшується з мінімумом через 7 діб і до 14-ї доби не досягає рівня контролю. Додаткове моделювання ішемії-реперфузії кінцівки на тлі гострої крововтрати супроводжується зниженням величини АПІ в тонкій кишці вже з 1 год експерименту, і протягом усього терміну спостереження вона $€$ істотно меншою, ніж в інших дослідних групах, що вказує на нашарування прооксидантних механізмів обох уражень.

\section{СПИСОК ЛІТЕРАТУРИ}

1. Point of injury tourniquet application during Operation Protective Edge-What do we learn? / A. Shlaifer, A. Yitzhak, E. N. Baruch [et al.] // J. Trauma Acute Care Surg. - 2017. - 83, № 2. - Р. 278-283.

2. Максимів Р.В.Динаміка балансуантиоксидантнопрооксидантних механізмів у внутрішніх органах під впливом артеріального джгута і реперсузії кінцівки / Р. В. Максимів, А. А. Гудима, В. М. Сидоренко // Шпитальна хірургія. Журн. імені Л. Я. Ковальчука. 2017. - № 1. - С. 37-44.

3. Горбань І. І. Вплив гострої крововтрати, ускладненої ішемією-реперфузією кінцівки, на антиоксидантно-прооксидантний баланс печінки та його корекція карбацетамом / І. І. Горбань // Здобутки клініч. і експерим. медицини. - 2020. - № 2. - С. 93-100.

4. Leukocytes and the inflammatory response in ischemiareperfusion injury /I. Francischetti, J. B. Moreno, M. Scholz, W. B. Yoshida // Rev. Bras. Cir. Cardiovasc. 2010. - 25 (4). - P. 575-584.

5. Murphy E. Mechanisms underlying acute protection from cardiac ischemia-reperfusion injury / E. Murphy, C. Steenbergen // Physiol. Rev. - 2008. 88 (2). - P. 581-609.

6. Гудима А. А. Антиоксидантно-прооксидантний та цитокіновий баланс у пізній період комбінованої травми в експерименті / А. А. Гудима, Т. В. Кащак, К. В. Шепітько // Світ медицини та біології. - 2019. № 1 (67). - C. 42-47.

7. Influence of two-hour tourniquets ischemia of limb and acute blood loss on systemic disorders of the body in the reperfusion period (experimental study) / I. I. Hor-

\section{REFERENCES}

1. Shlaifer, A., Yitzhak, A., Baruch, E.N., Shina, A., Satanovsky, A., Shovali, A., ..., \& Glassberg, E. (2017). Point of injury tourniquet application during Operation Protective Edge-What do we learn? J. Trauma Acute Care Surg., 83 (2), 278-283. DOI: 10.1097/ TA.0000000000001403.
3. Застосування впродовж 7-14 діб реперфузійного періоду карбацетаму у щурів із гострою крововтратою, ускладненою ішемією-реперфузією кінцівки, порівняно з тваринами без корекції, викликає істотне зростання величини АПІ в тонкій кишці, що свідчить про антиоксидантну дію препарату за умов модельованої патології.

Перспективи подальших досліджень. У майбутньому доцільно поглибити дослідження фрункціональних порушень тонкої кишки за умов гострої крововтрати й ішемії-реперфузії кінцівки та оцінити за цих умов ефективність дії карбацетаму.

ban, A. A. Hudyma, R. V. Maksymiv, I. V. Antonyshyn // Wiad. Lek. - 2020. - LXXIII, Issue 7. - P. 1330-1333. DOI: 10.36740/WLek202007104.

8. Шацький В. В. Динаміка антиоксидантно-прооксидантного балансу кіркового і мозкового шарів нирки після гострої крововтрати, ускладненої ішемією-реперфузією кінцівки, та його корекція карбацетамом / В. В. Шацький, А. А. Гудима, Л. Я. Федонюк // Здобутки клініч. і експерим. медицини. -2019. - № 4. С. 144-153.

9. Стахів О. В. Вплив гострої крововтрати, ускладненої ішемією-реперфузією кінцівки, на активність процесів ліпідної пероксидації у легенях та їх корекція карбацетамом / О. В. Стахів, Р. В. Максимів // Вісн. мед. і біол. дослідж. - 2020. - № 3 (5). - С. 108-114.

10. Козак Д. В. Вплив карбацетаму на антиоксидантно-прооксидантний баланс тканини серця, легень і печінки в динаміці політравми / Д. В. Козак // Шпитальна хірургія. - 2014. - № 1 (65). - С. 40-42.

11. Доклінічні дослідження лікарських засобів : метод. рек. / за ред. О. В. Стефранова. - К. : Авіцена, 2001. - 528 c.

12. Метод определения активности каталазы / М. А. Королюк, Л. И. Иванова, И. Г. Майорова, В. Е. Токарев // Лаб. дело. - 1988. - № 1. - С. 16-19.

13. Біохімічні зміни у сироватці крові щурів при ішемічно-реперфузійному синдромі (експериментальне дослідження) / А. А. Телев'як, Т. О. Вересюк, П. Р. Сельський, І. І. Боймиструк // Здобутки клініч. і експерим. медицини. - 2018. - № 2 (34). - С. 122-128.

14. Jeremy W. Hemorrhagic shock / W. Jeremy // N. Engl. J. Med. - 2018. - 378, № 4. - P. 370-379.

2. Maksymiv, R.V., Hudyma, A.A., \& Sydorenko, V.M. (2017). Dynamika balansu antyoksydantno-prooksydantnykh mekhanizmiv u vnutrishnikh orhanakh pid vplyvom arterialnoho dzhhuta i reperfuzii kintsivky [Dynamic of balance of antioxidant-prooxidant mechanism in internal organs Under the influence of blood har- 
nesses and limb reperfusion]. Shpytalna khirurhiia. Zhurnal imeni L.Ya. Kovalchuka - Hospital Surgery. Journal Named by L.Ya. Kovalchuk, 1, 37-44. DOI: 10.11603/2414-4533.2017.1.7637 [in Ukrainian].

3. Horban, I.I. (2020). Vplyv hostroi krovovtraty, uskladnenoi ishemiieiu-reperfuziieiu kintsivky, na antyoksydantno-prooksydantnyi balans pechinky ta yoho korektsiia karbatsetamom [The effect of acute blood loss complicated by limb ischemia-reperfusion on the antioxidant-prooxidant balance of the liver and its correction by carbacetam]. Zdobutky klinichnoi i eksperymentalnoi medytsyny - Achievements of Clinical and Experimental Medicine, 2, 93-100. DOI: https://doi.org/10.11603/18112471.2020.v.i2.11320 [in Ukrainian].

4. Francischetti, I., Moreno, J.B., Scholz, M., \& Yoshida, W.B. (2010). Leukocytes and the inflammatory response in ischemiareperfusion injury. Rev. Bras. Cir. Cardiovasc., 25 (4), 575-584. DOI: 10.1590/s010276382010000400023.

5. Murphy, E., \& Steenbergen, C. (2008). Mechanisms underlying acute protection from cardiac ischemia-reperfusion injury. Physiol. Rev., 88 (2), 581-609. DOI: 10.1152/ physrev.00024.2007.

6. Hudyma, A.A., Kashchak, T.V., \& Shepitko, K.V. (2019). Antyoksydantno-prooksydantnyi ta tsytokinovyi balans u piznii period kombinovanoi travmy $v$ eksperymenti [Antioxidant-prooxidant and cytokine balance in the late period of combined trauma in the experiment]. Svit medytsyny ta biolohiyi - World of Medicine and Biology, 1 (67), 42-47 [in Ukrainian].

7. Horban, I.I., Hudyma, A.A., Maksymiv, R.V., \& Antonyshyn, I.V. (2020). Influence of two-hour tourniquets ischemia of limb and acute blood loss on systemic disorders of the body in the reperfusion period (experimental study). Wiad. Lek., LXXIII, 7, 1330-1333.

8. Shatsky, V.V., Gudyma, A.A., \& Fedoniuk, L.Ya. (2019). Dynamika antyoksydantno-prooksydantnoho balansu kirkovoho i mozkovoho shariv nyrky pislia hostroi krovovtraty, uskladnenoi ishemiieiu-reperfuziieiu kintsivky, ta yoho korektsiia karbatsetamom [Dynamics of antioxidant-prooxidant balance of renal cortex and medulla after acute blood loss complicated by ischemia-reperfu- sion of the extremity, and its correction with carbacetam]. Zdobutky klinichnoi i eksperymentalnoi medytsyny Achievements of Clinical and Experimental Medicine, 4, 144-153. DOI: 10.11603/1811-2471.2019.v.i4.10815 [in Ukrainian].

9. Stakhiv, O.V., \& Maksymiv, R.V. (2020). Vplyv hostroi krovovtraty, uskladnenoi ishemiieiu-reperfuziieiu kintsivky, na aktyvnist protsesiv lipidnoi peroksydatsii u leheniakh ta yikh korektsiia karbatsetamom [Influence of acute blood loss complicated by limb ischemia-reperfusion on the activity of lipid peroxidation processes in lungs and their correction with carbacetam]. Visnyk medychnykh i biolohichnykh doslidzhen - Bulletin of Medical and Biological Research, 3 (5), 108-114. DOI: 10.11603/ bmbr.2706-6290.2020.3.11525 [in Ukrainian].

10. Kozak, D.V. (2014). Vplyv karbatsetamu na antyoksydantnyi-prooksydantnyi balans tkanyny sertsia, lehen i pechinky $v$ dynamitsi politravmy [Effect of carbacetam on antioxidant and prooxidant balance of heart lungs and liver tissues in polytrauma dynamic]. Shpytalna khirurhiia - Hospital Surgary, 1 (65), 40-42. DOI: https://doi.org/10.11603/1681-2778.2014.1.4362 [in Ukrainian].

11. Stefanov, O.V. (Ed.). (2001). Doklinichni doslidzhennia likarskykh zasobiv: metod. rekomendatsii [Preclinical studies of drugs: a method. recommendations]. Kyiv: Avitsenna [in Ukrainian].

12. Korolyuk, M.A., Ivanova, L.I., Mayorova, I.G., \& Tokarev, V.Ye. (1988). Metod opredeleniya aktivnosti katalazy [Method for determining the activity of catalase]. Labolatornoye delo - Laboratory Work, 1, 16-19 [in Russian].

13. Televiak, A.T., Veresiuk, T.O., Selskyy, P.R., \& Boymystruk, I.I. (2018). Biokhimichni zminy u syrovattsi krovi shchuriv pry ishemichno-reperfuziinomu syndromi (eksperymentalne doslidzhennia) [Biochemical changes in blood serum of rats with reperfusion-ischemic syndrome (the experimental study)]. Zdobutky klinichnoi i eksperymentalnoi medytsyny - Achievements of Clinical and Experimental Medicine, 2 (34), 122-128 [in Ukrainian].

14. Jeremy W. Hemorrhagic Shock. N. Engl. J. Med., $378,4,370-379$.

\section{ДИНАМИКА АНТИОКСИДАНТНО-ПРООКСИДАНТНОГО БАЛАНСА ТОНКОЙ КИШКИ ПОД ВЛИЯНИЕМ ОСТРОЙ КРОВОПОТЕРИ, ОСЛОЖНЕННОЙ ИШЕМИЕЙ-РЕПЕРФУЗИЕЙ КОНЕЧНОСТИ, И ЕГО КОРРЕКЦИЯ КАРБАЦЕТАМОМ}

\section{Резюме}

Вступление. Распространение терроризма и локальных вооруженных консрликтов привело к повышению частоты огнестрельных поражений с массивным внешним кровотечением из конечностей. Своевременное наложение кровоостанавливающего жгута на срок до 2 ч считают единственным средством спасения жизни. Однако влияние острой кровопотери и ишемии-реперфузии конечности на 
антиоксидантно-прооксидантный баланс тонкой кишки изучено недостаточно. Нет данных относительно эфроекттивности в этих условиях карбацетама, который проявляет антиоксидантное действие.

Цель исследования - выяснить влияние острой кровопотери, осложненной ишемией-реперфузией конечности, на антиоксидантно-прооксидантный баланс стенки тонкой кишки и эфрфективность коррекции выявленных нарушений карбацетамом.

Методы исследования. Эксперименты выполнены на 108 нелинейных крысах-самцах массой 200220 г. Всех животных разделили на 5 групп: контрольную и 4 исследовательских. Под тиопентал-натриевым наркозом в 1-й исследовательской группе моделировали ишемию-реперфузию конечности, во 2-й - острую кровопотерю, в 3-й - эти повреждения сочетали. В 4-й исследовательской группе крысам с острой кровопотерей и ишемией-реперфузией конечности внутрибрюшно вводили карбачетам в дозе 5 мг/кг массы тела животного. Через 1 и 2 ч, а также через 1, 7 и 14 суток в гомогенате тонкой кишки определяли содержание реагентов к тиобарбитуровой кислоте, каталазную активность, рассчитывали антиоксидантно-прооксидантный индекс (АПИ).

Результаты и обсуждение. Моделирование только ишемии-реперфузии конечности приводило к возрастанию величины АПИ в тонкой кишке с максимумом через 1 сутки эксперимента, что свидетельствовало о доминировании антиоксидантных механизмов в ответ на совокупность системных нарушений, которые возникают в организме в реперфузионный период. Под влиянием острой кровопотери величина АПИ в тонкой кишке в течение 1 и 2 ч эксперимента компенсаторно увеличивалась по сравнению с контролем, однако в дальнейшем резко уменьшалась и была существенно ниже контроля к 14-м суткам. Сочетание ишемии-реперфузии конечности и острой кровопотери было причиной уменьшения величины АПИ в тонкой кишке уже через 1 ч эксперимента. На протяжении всего срока наблюдения показатель в этой исследовательской группе был существенно ниже, чем в группах, в которых отдельно моделировали ишемию-реперфузию конечности и острую кровопотерю. Введение карбацетама нивелировало прооксидантное влияние исследуемого поражения на ткани тонкой кишки в течение 7-14 суток применения.

Выводы. Моделирование ишемии-реперфузии конечности на фоне острой кровопотери сопровождается уменьшением величины АПИ в тонкой кишке уже с 1 ч эксперимента, и на протяжении всего срока наблюдения она существенно ниже, чем в других исследовательских группах. Применение в течение 7-14 суток реперфузионного периода карбацетама способствует увеличению величины АПИ в тонкой кишке, что свидетельствует о антиоксидантном действии препарата в условиях моделируемой патологии.

КЛЮЧЕВЫЕ СЛОВА: тонкая кишка; острая кровопотеря; ишемия-реперфузия конечности; антиоксидантно-прооксидантный баланс; карбацетам.

\author{
V. V. Strelbytska, A. A. Hudyma \\ I. HORBACHEVSKY TERNOPIL NATIONAL MEDICAL UNIVERSITY
}

\title{
DYNAMICS OF ANTIOXIDANT-PROOXIDANT BALANCE OF THE SMALL INTESTINE UNDER THE INFLUENCE OF ACUTE BLOOD LOSS COMPLICATED BY ISCHEMIA-REPERFUSION OF THE LIMB, AND ITS CORRECTION WITH CARBACETAM
}

\section{Summary}

Introduction. The spread of terrorism and local armed conflicts has led to an increase in the frequency of gunshot injuries with massive external bleeding from the extremities. Timely application of a hemostatic tourniquet for up to two hours is considered the only way to save life. However, the effect of acute blood loss and ischemiareperfusion of the limb on the antioxidant-prooxidant balance of the small intestine has not been adequately studied. There is no data on the effectiveness under these conditions of carbacetam, which exhibits antioxidant effects.

The aim of the study - to elucidate the effect of acute blood loss, complicated by ischemia-reperfusion of the limb, on the antioxidant-prooxidant balance of the small intestine wall and the effectiveness of correction of the revealed disorders with carbacetam.

Research Methods. The experiments were carried out on 108 nonlinear male rats weighing 200-220 g. All animals were divided into five groups: control and four research groups. In thiopental sodium anesthesia in the first experimental group, limb ischemia-reperfusion was simulated, in the second - acute blood loss, in the third - these injuries were combined. In the fourth experimental group of animals with acute blood loss and ischemia-reperfusion 
of the limb, carbacetam was injected intraperitoneally at a dose of $5 \mathrm{mg}$ per kilogram of animal weight. After 1 and $2 \mathrm{~h}$, as well as after 1, 7 and 14 days in the homogenate of the small intestine, the content of reagents in thiobarbituric acid, the activity of catalase were determined, and the antioxidant-prooxidant index (API) was calculated.

Results and Discussion. Modeling only limb ischemia-reperfusion led to an increase in the value of API in the small intestine with a maximum after 1 day of the experiment, which indicates the dominance of antioxidant mechanisms in response to a set of systemic disorders that occur in the body during the reperfusion period. Under the influence of acute blood loss, the API value in the small intestine during 1 and $2 \mathrm{~h}$ of the experiment increased compensatory compared with the control, but then it sharply decreased and was significantly less than the control up to 14 days. The combination of limb ischemia-reperfusion and acute blood loss resulted in a decrease in the small intestine API value already after 1 hour of the experiment. During the entire observation period, the indicator in this study group was significantly lower than in the groups in which limb ischemia-reperfusion and acute blood loss were separately modeled. The introduction of carbacetam neutralized the prooxidant effect of the studied lesion on the tissue of the small intestine within 7-14 days of use.

Conclusions. Modeling of ischemia-reperfusion of a limb against the background of acute blood loss is accompanied by a decrease in the value of API in the small intestine already from 1 hour of the experiment and during the entire observation period is significantly less than in other experimental groups. The use of carbacetam for 7-14 days of the reperfusion period promotes an increase in the value of API in the small intestine, which indicates the antioxidant effect of the drug under conditions of the modeled pathology.

KEY WORDS: small intestine; acute blood loss; limb ischemia-reperfusion; antioxidant-prooxidant balance; carbacetam.

Отримано 22.03.21

Адреса для листування: А. А. Гудима, Тернопільський національний медичний університет імені І. Я. Горбачевського МОЗ України, майдан Волі, 1, Тернопіль, 46001, Україна, e-mail: arsgudyma@gmail.com. 